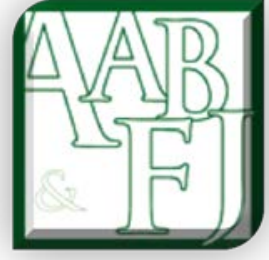

\title{
Technical Efficiency of Thai Manufacturing SMEs: A Stochastic Frontier Analysis
}

\author{
Teerawat Charoenrat ${ }^{1}$, Charles Harvie
}

\begin{abstract}
A major motivation of this study is to examine the factors that are the most important in contributing to the relatively poor efficiency performance of Thai manufacturing small and medium sized enterprises (SMEs). The results obtained will be significant in devising effective policies aimed at tackling this poor performance. This paper uses data on manufacturing SMEs in the North-eastern region of Thailand in 2007 as a case study, by applying a stochastic frontier analysis (SFA) and a technical inefficiency effects model. The empirical results obtained indicate that the mean technical efficiency of all categories of manufacturing SMEs in the North-eastern region is 43\%, implying that manufacturing SMEs have high levels of technical inefficiency in their production processes. Manufacturing SMEs in the North-eastern region are particularly labour-intensive. The empirical results of the technical inefficiency effects model suggest that skilled labour, the municipal area and ownership characteristics are important firm-specific factors affecting technical efficiency. The paper argues that the government should play a more substantial role in developing manufacturing SMEs in the North-eastern provinces through: providing training programs for employees and employers; encouraging a greater usage of capital and technology in the production process of SMEs; enhancing the efficiency of state-owned enterprises; encouraging a wide range of ownership forms; and improving information and communications infrastructure.
\end{abstract}

Keywords: Technical efficiency; Stochastic frontier analysis (SFA); Small and medium sized enterprises (SMEs); Manufacturing, North-eastern region of Thailand.

JEL Classification: C31, C87, D24

${ }^{1}$ Khon Kaen University, Nong Khai Campus, Nong Khai Province, Thailand, tc888@uowmail.edu.au 


\section{Introduction}

Small and medium sized enterprises (SMEs) are recognised as the most significant enterprises for accelerating Thai economic development (Regnier 2000; Tapaneeyangkul 2001; Brimble et al. 2002; Sahakijpicharn 2007). They represent 99\% of business establishments in the country and more than $75 \%$ of total employment during the period $1994^{2}$ to 2008 . The contribution of SMEs to total gross domestic product (GDP), at current prices, was approximately 38.95\% of total GDP over the period 1999-2008 (Office of Small and Medium Enterprises Promotion (OSMEP), 2008), According to Tapaneeyangkul (2001), SMEs play a significant role in encouraging income stability, economic growth and employment. They also contribute to regional development, poverty alleviation and economic empowerment for both minorities and women (Harvie 2008, p50), and are seen as being indispensable to the future sustainable development and growth of the economy (Wiboonchutikula 2002; OSMEP 2007a; OECD 2011)

A recent study by Charoenrat et al. (2010) found that there is a significant regional or provincial disparity in the technical efficiency performance of manufacturing SMEs. In particular, those SMEs located in the Northern and North-eastern provinces compared very unfavourably with those located elsewhere in the country. This was the case for aggregate manufacturing SMEs, by size of SME (small and medium) and for most manufacturing sub-sectors. A major motivation of this paper is to analyse in more detail the factors that contribute to the relatively poor performance of SMEs based in the North-eastern provinces of Thailand in particular. The results obtained will be important in facilitating the implementation of effective regional policies aimed at tackling this performance disparity. Otherwise, future income growth and economic development may lead to growing provincial income disparities and inefficient resource utilisation for the economy as a whole.

The primary aim of this study is to estimate the technical efficiency of manufacturing SMEs in the North-eastern region of Thailand in 2007, using stochastic frontier analysis (SFA) and a technical inefficiency effects model. Data for manufacturing SMEs in the North-eastern region is categorised into three categories: aggregate manufacturing SMEs; by size of SME (small and medium); and by three selected provinces in the North-eastern region. These categories are estimated individually to predict their technical efficiency and investigate whether this is positively or negatively related to firm-specific factors.

The paper proceeds as follows. The next section provides background on the SME sector in Thailand and reviews the literature. The Methodology section outlines the methodology adopted for this study. The following section discusses the data and key variables used in the study. The Model Specification section reviews the model specification adopted. The next section highlights the hypothesis tests to be conducted. The following section presents the key empirical results from the study. The final section presents a summary of the major findings from this study as well as key policy implications.

\footnotetext{
${ }^{2}$ The first year data on SMEs in Thailand has been compiled.
} 


\section{Background and Literature Review}

\section{Background}

The definition of an SME used in Thailand is generally based upon either the number of employees or the value of assets. Thus, an enterprise employing up to 50 workers, or with fixed assets, excluding land, not exceeding 50 million Thai baht (THB) (approximately US\$1.65 million) in the manufacturing sector is considered a small enterprise. An enterprise employing between 51-200 workers or with fixed assets, excluding land, between THB 51-200 million (approximately US\$1.686.6 million) is defined as a medium sized enterprise (Mephokee 2003; OSMEP 2003; Sahakijpicharn 2007). Focusing on the regional distribution of SMEs, Table 1 shows that Bangkok and its vicinity contained the highest number of SMEs. These represented 559,120 SMEs on average over the period 1994 to 2008, equivalent to around 30.5\% of total SMEs on average. Bangkok and its vicinity are recognised as the major economic centre and contain many of Thailand's large businesses (OSMEP 2007b). The second highest number of SMEs can be found in the North-eastern area, having 514,498 SMEs equivalent to $28.06 \%$ of all SMEs on average during 1994 to 2008. The Northern region was third, with 311,681 SMEs representing 17\% of all SMEs on average during 1994 to 2008. The fourth ranked region was the Central region, which accounted for 182,687 SMEs or 9.97\% of total SMEs on average during the period 1994-2008. The southern region was fifth with 159,959 SMEs during 1994-2008 on average, representing 8.73\% of total SMEs. The Eastern region had the lowest number of SMEs, accounting for 101,126 SMEs during the period 1994 to 2008, or 5.52\% of total SMEs on average. Finally, the remaining 4,203 enterprises in 1994-2008, or $0.23 \%$ of overall SMEs on average, are not specified by region (OSMEP 2001, 2002, 2003, 2004, 2005, 2006, 2007a, 2008).

While SMEs make a significant contribution to the Thai economy, they face a number of severe problems that act as barriers to their further development. These include: lack of management and/or administration skills; limitation of marketing skills; lack of technology and innovation skills; difficulty in gaining access to government funding and credit institutions; poor competitiveness and entrepreneurial skills; lack of integration into domestic and international markets; and lack of transparency and good book-keeping (Regnier 2000; Brimble et al. 2002; Mephokee 2003; Sahakijpicharn 2007; OSMEP 2008). In addition, for many years the government has paid little attention to SMEs. Government agencies are not well-prepared to play an effective role in assisting SME performance to enable them to be more competitive in the domestic and international marketplace (Tapaneeyangkul 2001; Mephokee 2003; Sahakijpicharn 2007). According to Gregory et al. (2002), SMEs have to strengthen and improve their cooperation and integration with both domestic and overseas enterprises with the aim of maintaining their competitiveness and enhancing their knowledge and technology.

This study aims to estimate the technical efficiency of manufacturing SMEs in the Northeastern region, and firm-specific factors which affect this efficiency. As identified by Charoenrat et al. (2010) SMEs appear to face distinct problems in this region, and this is an issue which has not been previously empirically examined in the literature. This study will estimate the technical efficiency of manufacturing SMEs in the North-eastern region of Thailand and firm-specific factors contributing to technical inefficiency: by size of manufacturing SMEs (small and medium); by aggregate manufacturing SMEs; and by three selected provinces in the North-eastern region: the Khon Kaen, Udon Thani and Nong Khai provinces. According to the Office of Small and Medium Enterprises Promotion (2008), the Khon Kaen province contains the highest number of SMEs over the period 2001 to 2008 in the North-eastern region. The Udon Thani province has the third highest number of SMEs in the North-eastern region. The Nong Khai province is recognised as the major city for border trade between Thailand and Laos. Potential firm-specific factors contributing to the technical inefficiency of Thai manufacturing SMEs from the literature are: (1) firm size; (2) firm age; (3) skilled labour intensity; (4) firm location (municipal and non-municipal areas); and (5) 
ownership characteristics (i.e. individual proprietor, juristic partnership, limited company, stateenterprise, and co-operatives). The analysis conducted uses firm-level data obtained from the 2007 industrial census ${ }^{3}$ conducted by the National Statistical Office (NSO) of Thailand (NSO 2011).

Table 1

Number and Percentage of SMEs Classified by Region, 1994-2008

\begin{tabular}{|c|c|c|c|c|c|c|c|c|c|}
\hline Regions & 1994 & 1999 & 2002 & 2003 & 2004 & 2005 & 2006 & 2007 & 2008 \\
\hline $\begin{array}{l}\text { Bangkok and } \\
\text { vicinity }\end{array}$ & 119,609 & 157,730 & 517,827 & 611,535 & 660,389 & 674,838 & 692,922 & 728,518 & 868,715 \\
\hline Central & 82,673 & 85,795 & 202,411 & 203,585 & 186,516 & 190,061 & 195,970 & 198,620 & 298,548 \\
\hline Northern & 81,168 & 76,640 & 298,124 & 300,490 & 386,232 & 387,585 & 395,611 & 400,126 & 479,154 \\
\hline North-eastern & 111,712 & 121,940 & 514,245 & 524,515 & 623,682 & 625,402 & 650,469 & 689,015 & 769,503 \\
\hline Southern & 36,539 & 70,442 & 29,015 & 246,951 & 213,699 & 215,588 & 197,394 & 201,456 & 228,547 \\
\hline Eastern & 5,304 & 10,459 & 76,658 & 107,753 & 125,338 & 129,210 & 137,825 & 138,925 & 178,659 \\
\hline Unspecified & 1,800 & 1,954 & 1,147 & 1,100 & 3,739 & 16,596 & 4,334 & 2,652 & 4,507 \\
\hline Total & 438,805 & 524,960 & $1,639,427^{4}$ & $1,995,929$ & 2,199,595 & $2,239,280$ & $2,274,525$ & $2,359,312$ & 2,827,633 \\
\hline Regions & 1994 & 1999 & 2002 & 2003 & 2004 & 2005 & 2006 & 2007 & 2008 \\
\hline $\begin{array}{l}\text { Bangkok and } \\
\text { vicinity }\end{array}$ & 27.26 & 30.05 & 31.59 & 30.64 & 30.02 & 30.14 & 30.46 & 30.88 & 30.72 \\
\hline Central & 18.84 & 16.34 & 12.35 & 10.20 & 8.48 & 8.49 & 8.62 & 8.42 & 10.56 \\
\hline Northern & 18.50 & 14.60 & 18.18 & 15.06 & 17.56 & 17.31 & 17.39 & 16.96 & 16.95 \\
\hline North-eastern & 25.46 & 23.23 & 31.37 & 26.28 & 28.35 & 27.93 & 28.60 & 29.20 & 27.21 \\
\hline Southern & 8.33 & 13.42 & 1.77 & 12.37 & 9.72 & 9.63 & 8.68 & 8.54 & 8.08 \\
\hline Eastern & 1.21 & 1.99 & 4.68 & 5.40 & 5.70 & 5.77 & 6.06 & 5.89 & 6.32 \\
\hline Unspecified & 0.41 & 0.37 & 0.07 & 0.06 & 0.17 & 0.74 & 0.19 & 0.11 & 0.16 \\
\hline Total & 100 & 100 & 100 & 100 & 100 & 100 & 100 & 100 & 100 \\
\hline
\end{tabular}

Source: Office of Small and Medium Enterprises Promotion (2001-2008).

\footnotetext{
${ }^{3}$ Firm-level data in the 2007 industrial census covered the operations of firms from $1^{\text {st }}$ January 2006 to $31^{\text {st }}$ December 2006 (National Statistical Office of Thailand (NSO) 2011).

${ }^{4}$ The database for SMEs in 2002 indicated that some were unidentified in terms of region. This may have contributed to the volatility of SME numbers after 1999 (Office of Small and Medium Enterprises Promotion (OSMEP) 2003; Sahakijpicharn 2007).
} 


\section{Literature Review}

Arunsawadiwong (2007) studied productivity trends in the Thai manufacturing sector. The author employed stochastic frontier analysis (SFA) to measure the pre- and post-financial crisis technical efficiency levels of this sector. The periods for estimation were divided into two sub-periods; the prefinancial crisis covering 1990 to 1996, and the post-financial crisis covering 1997 to 2002. The results reveal that the overall efficiency of the manufacturing sector improved in the post-crisis period, compared to the pre-crisis period. The post-crisis period showed some technical efficiency changes from year to year, indicating that the manufacturing sector was becoming more attentive in improving its efficiency as compared to the pre-crisis period, which experienced no obvious technical efficiency improvement. The findings indicated that a structural shift in the Thai manufacturing sector had occurred, from being labour intensive in the pre-crisis period to being capital intensive in the post-crisis period. The level of productivity improved in the post-crisis period when compared to the pre-crisis level. The low productive investment level in the pre-crisis period is recognised as the main factor that led to a decline in the efficiency of the manufacturing sector. The author concludes that this low productivity level caused a decline in manufacturing sector competitiveness.

Wiboonchutikula (2002) investigated trends in the SME sector in Thailand, focusing upon employment, export ability and subcontracting activity. Industrial census data for 1997 is used in the study from the National Statistical Office (NSO) of Thailand. The author uses technical efficiency and total factor productivity (TFP) as measures to analyse the productivity of small and medium sized firms. A Translog frontier production function is used to estimate technical efficiency indices. The study shows that over the period 1987 to 1996 the SME share of overall employment declined from $60 \%$ to $52 \%$. This was particularly noticeable for the small firm category, defined as firms with less than 50 employees. This is explored further by considering small firm employment shares in three sub-periods with varying overall economic growth rates. It is shown that when overall economic growth is high, then the share of small firms in total employment seems to contract, possibly because several small firms develop into medium sized firms and others disappear because their owners can obtain more remunerative work in larger firms. However, during slower growth rate periods, the proportion of employment in small firms tends to increase, because larger firms may hire less new employees, downsize or lay off employees.

Tran et al. (2008) estimated the efficiency performance of non-state small and medium sized manufacturing firms in Vietnam using stochastic frontier analysis and firm level data covering the period 1996 to 2001. They find that the average efficiency levels of non-state small and medium sized manufacturing industries increased over the period 1996 to 2001. Micro-enterprises and firms located in a metropolitan area are positively associated with higher technical efficiency. The efficiency benefits from a micro-enterprise can be explained by the benefits arising from family labour and a reduced incidence of shirking. The metropolitan efficiency effect is suggestive of agglomeration economies in the private sector, as a consequence of increased availability of more highly educated workers and managers, and market opportunities in metropolitan locations relative to non-metropolitan locations. Firm age is associated with lower efficiency levels, which can be attributed to a legacy of discrimination against private sector SMEs. The findings from this study also indicate limited benefits from government support in terms of credit and non-financial assistance to firms, as this support does not seem to be systematically based upon any performance criteria. It is also recommend that the Vietnamese government strengthen technical assistance and practical policies in order to improve firm level technical efficiency.

Zahid and Mokhtar (2007) estimated the technical efficiency levels of Malaysian manufacturing SMEs. The authors used cross-sectional data for manufacturing industries compiled by the Department of Statistics of Malaysia in 2002. A Cobb-Douglas stochastic production frontier is applied in order to estimate technical efficiency levels. The results presented indicate that all 
coefficients in the stochastic production frontier are positive and significant. This indicates that inputs have a positive relationship, and are significant, for the production levels of manufacturing SMEs. The average technical efficiency of overall manufacturing SMEs is found to be $76 \%$, hence Malaysian manufacturing SMEs are approximately 24\% inefficient in their production processes. The authors suggest that the Malaysian government should play a role in improving the performance of manufacturing SMEs such as through training programs for employees and by means of appropriate financial assistance.

\section{Methodology}

The two most commonly used techniques for estimating a production frontier and predicting maximum possible firm output are data envelopment analysis (DEA) and stochastic frontier analysis (SFA) (Coelli 1996a, 1996b; Kontodimopoulos et al. 2010). DEA is a non-parametric approach that involves the use of linear programming to construct a frontier. It does not require assumptions concerning the form of the production function (Coelli 1996b). The best practice production function is created empirically from observed input and output. DEA does not identify the difference between technical inefficiency and random error (Admassie \& Matambalya 2002; Vu 2003; Coelli et al. 2005). On the other hand SFA is a parametric approach, where the form of the production function is assumed to be known or is estimated statistically. SFA also allows other parameters of the production technology to be explored (Coelli 1996a; Greene 2003; Coelli et al. 2005). The advantages of this approach are that hypotheses can be tested with statistical rigour, and that relationships between input and output follow known functional forms. SFA enables the simultaneous estimation of technical efficiency and a technical inefficiency effects model (Admassie \& Matambalya 2002; Coelli et al. 2005; Arunsawadiwong 2007; Zahid \& Mokhtar 2007).

SFA is the approach used to conduct the empirical analysis for this study. SFA achieves the objectives of this study by providing reliable and unbiased measurement of the technical efficiency levels of manufacturing SMEs in the North-eastern region. SFA utilises the technique of maximum likelihood to calculate a wide variety of stochastic frontier models, based on Cobb-Douglas and the Transcendental-logarithm (Translog) production functions (Coelli 1996a; Coelli et al. 2005).

\section{Data and Key Variables}

Data used in this study comes from the 2007 industrial census, compiled by the National Statistics Office (NSO) of Thailand (NSO 2011). Establishments under the scope of this census are those engaged primarily in the manufacturing industry (category D International Standard Industrial Classification of All Economic Activities; ISIC: Revision 3) (UNSD 2011). The 2007 industrial census covered all establishments with 10 or more employed persons in all regions throughout the nation. The census used a Stratified Systematic Sampling methodology. Regions and provinces or cities were constituted as strata while type of industrial activities and groups of industrial establishment were constituted sub-stratum. The sampling units were establishments. An interview method was employed in the data collection (NSO 2011). 
However this study only focuses on Thai manufacturing SMEs for the three selected provinces in the North-eastern region, the Khon Kaen, Udon Thani and Nong Khai provinces. The total number of manufacturing SMEs in the North-eastern region is 13,176 . Data ${ }^{5}$ for manufacturing SMEs in the North-eastern region is categorised into three aspects: by aggregate manufacturing SMEs; by size of SME; and by the selected three provinces in the North-eastern region, the Khon Kaen, Udon Thani and Nong Khai provinces, respectively.

Data extracted for manufacturing SMEs in the North-eastern region were based upon that required to estimate the Cobb-Douglas and Translog production functions, and included output value added $(Y)$, labour input $(L)$ and capital input $(K)$. Output value added $(Y)$ is measured as the value of gross output minus intermediate consumption and it is used as output production. Labour input $(L)$ is measured as the total number of workers in the establishment, including owner or partner, unpaid workers, skilled labour and unskilled labour. Capital input $(K)$ is measured as the net value of fixed assets after deducting the accumulated depreciation at the end of the year. The net value of fixed assets is a combination of land, buildings, construction, machinery and equipment, vehicles, office appliances and software.

\section{Model Specification}

Technical efficiency and the technical inefficiency effects models for manufacturing SMEs in the North-eastern region can be estimated using both Cobb-Douglas and Translog production functions. Coelli (1996a) emphasised that the Cobb-Douglas and Translog production functions are the most often used functional forms for stochastic frontier analysis. Both the Cobb-Douglas and the Translog production functions are tested in this study for adequate functional form (see Kim 2003; Vu 2003; Tran et al. 2008; Amornkitvikai \& Harvie 2011). A Cobb-Douglas production function using crosssectional data may be expressed as follows (Coelli 1996a):

$$
\ln Y_{i}=\beta_{0}+\beta_{1} \ln \left(K_{i}\right)+\beta_{2} \ln \left(L_{i}\right)+\left(V_{i}-U_{i}\right), \mathrm{i}=1, \ldots, \mathrm{N},
$$

The Translog production function using cross-sectional data can be written as follows (Coelli 1996a):

$$
\ln Y_{i}=\beta_{0}+\beta_{1} \ln \left(K_{i}\right)+\beta_{2} \ln \left(L_{i}\right)+\beta_{3} \ln \left(K_{i}\right)^{2}+\beta_{4} \ln \left(L_{i}\right)^{2}+\beta_{5} \ln \left(K_{i}\right) \ln \left(L_{i}\right)+\left(V_{i}-U_{i}\right)
$$

where $Y_{i}$ denotes value added, $K_{i}$ represents the net value of fixed assets, $L_{i}$ represents the total number of employees, $V_{i}$ is a random error term with zero mean that has an independently identical distribution $v_{i}$ : $\operatorname{iidN}\left(0, \sigma_{v}^{2}\right)$ and is assumed to be independently distributed of $U_{i}$ (Coelli et al. 2005; Tran et al. 2008). $U_{i}$ is a one-sided error term assumed to be a non-negative variable $u_{i}$ : $i i d N^{+}\left(0, \sigma_{u}^{2}\right)$ and is a technical inefficiency term (Coelli et al. 2005; Tran et al. 2008). The

\footnotetext{
${ }^{5}$ A brief description and summary of the key statistics for selected variables used in the stochastic production functions and technical inefficiency effects model for aggregate manufacturing SMEs, by size of SMEs and by the selected three provinces, are available from the authors on request.
} 
subscript $i$ refers to firms. $\beta$ is a vector of unknown parameters, with $\beta_{0}$ representing the intercept term, $\beta_{1}$ representing the coefficient estimates of the capital input parameter, and $\beta_{2}$ representing the coefficient estimates of the labour input parameter.

The technical inefficiency effects model can be expressed as follows:

$$
\begin{aligned}
U_{i}=\delta_{0} & +\delta_{1} \text { size }_{i}+\delta_{2} \text { age }_{i}+\delta_{3} \text { skill }_{i}+\delta_{4} \text { municipal }_{i}+\delta_{5} \text { individual }_{i}+\delta_{6} \text { juristic }_{i} \\
& +\delta_{7} \text { public }_{i}+\delta_{8} \text { government }_{i}+\delta_{9} \text { co- } \text { operative }_{i}+\omega_{i}
\end{aligned}
$$

where Size is a dummy variable that takes the value 1 for small enterprises employing up to 50 workers and 0 for medium-sized enterprises employing between 51-200 workers. Age is the number of years calculated since a firm's establishment. Skill is calculated as the ratio of skilled labour in the production process to total labour input. Municipal is a dummy variable for a municipal area that takes the value 1 if a firm is located in a particular municipal area and 0 otherwise. Individual is a dummy variable that takes the value 1 for an individual proprietor and 0 otherwise. Juristic is a dummy variable for juristic partnership that takes the value 1 if a firm is a juristic partnership and 0 otherwise. Public is a dummy variable that takes the value 1 for a public limited company and 0 otherwise. Government is a dummy variable that takes the value 1 for a government-owned enterprise and 0 otherwise. Co-operative is a dummy variable for a co-operative that takes the value 1 if a firm is a co-operative and 0 otherwise. $\delta$ is a vector of unknown coefficients to be estimated. $\omega_{i}$ can be defined as the truncation of the normal distribution $N\left(0, \sigma_{\omega}^{2}\right)$, the position of truncation is $-\left(\delta_{0}+z_{i} \delta\right)$ (Coelli et al. 2005; Tran et al. 2008).

The coefficients of the production frontier and technical inefficiency effects model can be measured using the maximum likelihood method under the assumption of a normal distribution for $U_{i}$ (Coelli et al. 2005; Tran et al. 2008). The appropriateness of the stochastic frontier approach can be tested by calculating the value of the parameter $\gamma$ (Battese \& Corra 1977; Coelli et al. 2005), which contains a value between 0 and 1 and depends on two variance parameters of the stochastic frontier function. This is defined as follows (Battese \& Corra 1977; Coelli et al. 2005):

$$
\gamma=\frac{\sigma_{u}^{2}}{\sigma^{2}} \text {, where } \sigma^{2}=\sigma_{v}^{2}+\sigma_{u}^{2}
$$

$\sigma_{v}^{2}$ and $\sigma_{u}^{2}$ are variances of the noise and inefficiency effects. If the value $\gamma$ is close to zero deviations from the frontier are attributed to noise, whereas a value close to unity indicates that deviations are ascribed to technical inefficiency (Coelli et al. 2005; Tran et al. 2008).

\section{Hypothesis Tests}

The estimation of a stochastic frontier production function can be used to test the validation of three hypotheses as follows: (1) adequacy of the Cobb-Douglas production functional form; (2) absence of technical inefficiency effects; and (3) insignificance of joint inefficiency variables. Formal hypotheses tests associated with the stochastic production function and technical inefficiency effects models are presented in Tables 2, 3 and 4, respectively. Three hypothesis tests are conducted by using the generalised likelihood-ratio test (LR test), which can be defined as (see Kim 2003; Coelli et al. 2005; Tran et al. 2008; Amornkitvikai \& Harvie 2011): 


$$
\lambda=-2\left\{\log \left[L\left(H_{0}\right)\right]-\log \left[L\left(H_{1}\right)\right]\right\}
$$

where $\log \left[L\left(H_{0}\right)\right]$ and $\log \left[L\left(H_{1}\right)\right]$ are the values of a log-likelihood function for the frontier model under the null hypothesis $\left(H_{0}\right)$ and the alternative hypothesis $\left(H_{1}\right)$. The LR test statistic contains an asymptotic chi-square $\left(\chi^{2}\right)$ distribution with parameters equal to the number of restricted parameters imposed under the null hypothesis $\left(H_{0}\right)$, except hypotheses (2) and (3) which contain a mixture of a chi-square $\left(\chi^{2}\right)$ distribution (Kodde \& Palm 1986). Hypotheses (2) and (3) involve the restriction that $\lambda$ is equal to zero which defines a value on the boundary of the parameter space (Coelli 1996a, p6).

Table 2 presents results of the hypothesis tests for aggregate manufacturing SMEs and the selected three provinces in the North-eastern region. From Table 2 the first null hypothesis $\left(H_{0}\right)$ tests whether a Cobb-Douglas or Translog production function is adequate for aggregate manufacturing SMEs and for the selected three provinces in the North-eastern region. Following Equations (1) and (2), the first null hypothesis $\left(H_{0}=\beta_{3}=\beta_{4}=\beta_{5}=0\right)$ is strongly rejected at the $1 \%$ level of significance for the Khon Kaen and Udon Thani provinces, except for the aggregate manufacturing SMEs and the Nong Khai province. Thus, the Cobb-Douglas production function is not an adequate specification for the Khon Kaen and Udon Thani provinces. Instead, an adequate functional form for aggregate manufacturing SMEs and the Nong Khai province is the CobbDouglas production function. However, the Translog production function generates an inadequate estimation of returns to scale, since the magnitude of the estimated coefficients is too large. Therefore, this study will employ a Cobb-Douglas production function for manufacturing SMEs in the Khon Kaen and Udon Thani provinces, as specified by Equation (1). Several empirical studies have used the Cobb-Douglas production function in their analyses (Battese \& Coelli 1995; Admassie \& Matambalya 2002; Batra \& Tan 2003; Vu 2003; Phan 2004; Arunsawadiwong 2007). In addition, the Cobb-Douglas functional form is easy to estimate and mathematically simple to manipulate, but it is restrictive in the properties that it imposes on the production structure such as fixed returns to scale and the elasticity of substitution being equal to unity. The Translog functional form does not impose these restrictions on the production structure, but this comes at the cost of having a form which is more difficult to mathematically manipulate, and can suffer from degrees of freedom and multicollinearity problems (Coelli 1995; Coelli et al. 2005).

The second null hypothesis $\left(H_{0}\right)$, which specifies that technical inefficiency effects are absent from the model $\left(H_{0}: \gamma=\delta_{0}=\delta_{1}=\cdots=\delta_{10}=0\right)$, is strongly rejected at the $1 \%$ level of significance. This implies that the technical inefficiency effects model exists for aggregate manufacturing SMEs, the Khon Kaen, Udon Thani and Nong Khai provinces, given a Cobb-Douglas production function and inefficiency effects model, as defined by Equations (1) and (3). The last null hypothesis $\left(H_{0}\right)$ specifies that all estimated parameters of the explanatory variables in the inefficiency effects model are equal to zero $\left(H_{0}: \delta_{1}=\delta_{2}=\cdots=\delta_{10}=0\right)$. The null hypothesis $\left(H_{0}\right)$ is strongly rejected at the $1 \%$ level of significance for the case of aggregate manufacturing SMEs, and the Khon Kaen, Udon Thani and Nong Khai provinces (see Table 2), indicating that the joint inefficiency effect of the explanatory variables is statistically significant, given the Cobb-Douglas production function and inefficiency effects model. 
Table 2

Statistics for Hypothesis Tests of the Stochastic Frontier Model and Inefficiency Effects Model by Aggregate Manufacturing SMEs and Three Selected Provinces

\begin{tabular}{|c|c|c|c|c|}
\hline & $\begin{array}{c}\text { Aggregate Manufacturing } \\
\text { SMEs }\end{array}$ & Khon Kaen Province & Udon Thani Province & Nong Khai Province \\
\hline Null Hypothesis & \multicolumn{4}{|c|}{$\begin{array}{l}\text { (1) Cobb-Douglas Production Function } \\
\qquad\left(H_{0}=\beta_{3}=\beta_{4}=\beta_{5}=0\right)\end{array}$} \\
\hline LR Statistics & 0.56 & 12.87 & 27.20 & 2.12 \\
\hline Critical Value & \multicolumn{4}{|c|}{11.34} \\
\hline Decision & Do not reject $H_{0}$ & Reject $H_{0}$ & Reject $H_{0}$ & Do not reject $H_{0}$ \\
\hline Null Hypothesis & \multicolumn{2}{|c|}{$\left(H_{0}: \gamma=\delta_{0}=\delta_{1}=\cdots=\delta_{10}=0\right)$} & & \\
\hline LR Statistics & 1525.50 & 350.00 & 138.96 & 94.78 \\
\hline Critical Value & \multicolumn{4}{|c|}{$25.55^{*}$} \\
\hline Decision & Reject $H_{0}$ & Reject $H_{0}$ & Reject $H_{0}$ & Reject $H_{0}$ \\
\hline Null Hypothesis & \multicolumn{4}{|c|}{$\begin{array}{l}\text { (3) No joint Inefficiency Variables } \\
\left(H_{0}: \delta_{1}=\delta_{2}=\cdots=\delta_{10}=0\right)\end{array}$} \\
\hline LR Statistics & 1228.73 & 329.32 & 135.90 & 58.40 \\
\hline Critical Value & \multicolumn{4}{|c|}{23.21} \\
\hline Decision & Reject $H_{0}$ & Reject $H_{0}$ & Reject $H_{0}$ & Reject $H_{0}$ \\
\hline
\end{tabular}

Note: All critical values of the test statistic are presented at the $1 \%$ level of significance, obtained from a $\chi^{2}$ distribution, except where indicated by *, which contain a mixture of a $\chi^{2}$ distribution obtained from Table 1 of Kodde and Palm (1986).

In Table 3 the first null hypothesis $\left(H_{0}=\beta_{3}=\beta_{4}=\beta_{5}=0\right)$ tests whether a Cobb-Douglas or Translog production function is an adequate functional form for small and medium-sized enterprises separately. Following Equations (1) and (3), the null hypothesis $\left(H_{0}\right)$ is not statistically significant at the $1 \%$ level of significance for the size of SMEs. Thus, the Cobb-Douglas production function is an adequate functional form for the case of small and medium-sized enterprises separately, as specified by Equation (1). The second null hypothesis $\left(H_{0}: \gamma=\delta_{0}=\delta_{1}=\cdots=\delta_{9}=0\right)$, which specifies that technical inefficiency effects are absent from the model, is strongly rejected at the $1 \%$ level of significance. This implies that the traditional response model is not an adequate representation of the data for small and medium sized-enterprises separately, given the CobbDouglas production function and inefficiency effects model, as specified by Equations (1) and (3). The last null hypothesis $\left(H_{0}: \delta_{1}=\delta_{2}=\cdots=\delta_{9}=0\right)$ specifies that the inefficiency effects are not a linear function in the model. The null hypothesis $\left(H_{0}\right)$ is strongly rejected at the $1 \%$ level of significance for small and medium-sized enterprises separately, implying that the joint inefficiency effect of the explanatory variables is statistically significant, given a Cobb-Douglas production function and inefficiency effects model. 
Table 3

Statistics for Hypothesis Tests of the Stochastic Frontier Model and Inefficiency Effects Model by Size of SMEs

\begin{tabular}{|c|c|c|}
\hline & Small Enterprises & Medium Enterprises \\
\hline Null Hypothesis & \multicolumn{2}{|c|}{$\begin{array}{l}\text { (1) Cobb-Douglas Production Function } \\
\qquad\left(H_{0}=\beta_{3}=\beta_{4}=\beta_{5}=0\right)\end{array}$} \\
\hline LR Statistics & 2.09 & 0.49 \\
\hline Critical Value & \multicolumn{2}{|c|}{11.34} \\
\hline Decision & Do not reject $H_{0}$ & Do not reject $H_{0}$ \\
\hline Null Hypothesis & \multicolumn{2}{|c|}{ (2) No technical inefficiency Effects } \\
\hline LR Statistics & 1510.62 & 144.43 \\
\hline Critical Value & \multicolumn{2}{|c|}{ 24.05* } \\
\hline Decision & Reject $H_{0}$ & Reject $H_{0}$ \\
\hline Null Hypothesis & \multicolumn{2}{|c|}{ (3) No joint Inefficiency Variables } \\
\hline LR Statistics & 1217.87 & 141.77 \\
\hline Critical Value & \multicolumn{2}{|c|}{21.67} \\
\hline Decision & Reject $H_{0}$ & Reject $H_{0}$ \\
\hline
\end{tabular}

Note: All critical values of the test statistic are presented at the $1 \%$ level of significance, obtained from a $\chi^{2}$ distribution, except where indicated by *, which contain a mixture of a $\chi^{2}$ distribution obtained from Table 1 of Kodde and Palm (1986).

\section{Empirical Results}

The maximum likelihood estimates for parameters of a stochastic frontier model and technical inefficiency effects model, as specified by Equations (1) and (3), are estimated simultaneously utilising the econometric package Frontier 4.1. The estimated results for Equations (1) and (3) are provided in Tables 4 and 5. The estimation of the technical inefficiency effects model is presented in Table 6. A summary for the average technical efficiency of manufacturing SMEs in the Northeastern region is presented in Table 7.

\section{Results for Input Elasticities and Gamma Parameters}

Table 4 presents the results of the maximum likelihood estimation for aggregate manufacturing SMEs and small and medium-sized enterprises separately. In the Cobb-Douglas production function it is found that aggregate manufacturing SMEs and small and medium-sized enterprises have positive signs for both capital $\left(\beta_{1}\right)$ and labour $\left(\beta_{2}\right)$, and they are also highly significant at the $1 \%$ level of significance. Aggregate manufacturing SMEs, small and medium-sized enterprises are found to have increasing returns to scale, because the combined values of the estimated input coefficients are greater than unity, being 1.373, 1.456 and 1.222 respectively. However, it is important to note that there are different elasticities for each of aggregate manufacturing SMEs, small and medium-sized enterprises. The elasticities of labour $\left(\beta_{2}\right)$ in the stochastic production functions are much higher than capital $\left(\beta_{1}\right)$. From Table 4 , the elasticities of labour $\left(\beta_{2}\right)$ for aggregate manufacturing SMEs, small and medium-sized enterprises are equal to 1.152, 1.254 and 1.017 , respectively. The capital $\left(\beta_{1}\right)$ elasticities for aggregate manufacturing SMEs, small and medium-sized enterprises, are 0.221, 
0.202 and 0.205, respectively. The high labour elasticity values indicate that aggregate manufacturing SMEs, small and medium-sized enterprises are labour intensive, and that this is the most important factor in the production function. The low capital elasticity value in the production function reveals that this factor is much less important in the production functions for aggregate manufacturing SMEs, small and medium-sized enterprises.

\section{Table 4}

Maximum Likelihood Estimates for Parameters of the Stochastic Frontier Model and Technical Inefficiency Effects Model by Aggregate Manufacturing SMEs, Small Enterprises and Medium Enterprises

\begin{tabular}{|c|c|c|c|c|c|c|}
\hline \multirow{3}{*}{$\begin{array}{ll}\text { Variables } & \\
& \text { Number of Observations }\end{array}$} & \multicolumn{2}{|c|}{ Aggregate Manufacturing SMEs } & \multicolumn{2}{|c|}{ Small Enterprises } & \multicolumn{2}{|c|}{ Medium Enterprises } \\
\hline & \multicolumn{2}{|c|}{13176} & \multicolumn{2}{|c|}{12652} & \multicolumn{2}{|r|}{524} \\
\hline & Coefficients & Standard Error & Coefficients & Standard Error & Coefficients & Standard Error \\
\hline \multicolumn{7}{|l|}{ Stochastic Frontier Model } \\
\hline Constant & $4.526 * * *$ & 0.057 & $4.558 * * *$ & 0.062 & $5.019 * * *$ & 0.709 \\
\hline Capital & $0.221^{* * *}$ & 0.005 & $0.202 * * *$ & 0.006 & $0.205^{* * *}$ & 0.026 \\
\hline Labour & $1.152^{* * *}$ & 0.013 & $1.254 * * *$ & 0.014 & $1.017 * * *$ & 0.132 \\
\hline \multicolumn{7}{|l|}{ Technical Inefficiency Effects Model } \\
\hline Constant & $1.982 * * *$ & 0.115 & $2.063 * * *$ & 0.053 & $1.496 * * *$ & 0.315 \\
\hline Firm Size (dummy) & -0.135 & 0.110 & N/A & N/A & N/A & N/A \\
\hline Firm Age ${ }^{6}$ (year) & 0.000 & 0.002 & -0.000 & 0.001 & -0.002 & 0.006 \\
\hline Skilled Labour (ratio) & $-0.431 * * *$ & 0.043 & $-0.346 * * *$ & 0.038 & $0.414 * *$ & 0.167 \\
\hline Municipality (dummy) & $-0.643^{* * *}$ & 0.046 & $-0.542 * * *$ & 0.041 & 0.306 & 0.197 \\
\hline Individual Proprietor (dummy) & $-0.651 * * *$ & 0.046 & $-0.730 * * *$ & 0.037 & $-0.584 * *$ & 0.284 \\
\hline Juristic Partnership (dummy) & $-3.571 * * *$ & 0.334 & $-2.856^{* * *}$ & 0.361 & $-1.351 * * *$ & 0.225 \\
\hline Limited \& Public limited company (dummy) & $-7.210 * * *$ & 0.161 & $-5.468 * * *$ & 0.460 & $-1.782 * * *$ & 0.279 \\
\hline Government \& State enterprises (dummy) & $1.259^{* * *}$ & 0.278 & -0.242 & 0.399 & $1.709 * * *$ & 0.417 \\
\hline Cooperatives (dummy) & $-0.908 * *$ & 0.470 & $-1.021^{* *}$ & 0.401 & -0.581 & 0.767 \\
\hline \multicolumn{7}{|l|}{ Variance Parameters } \\
\hline Sigma-squared & $1.488 * * *$ & 0.027 & $1.332 * * *$ & 0.025 & $1.122 * * *$ & 0.074 \\
\hline Gamma & $0.411^{* * *}$ & 0.019 & $0.204 * * *$ & 0.042 & 0.001 & 0.020 \\
\hline Log-likelihood Function & -20421.62 & & -19577.87 & & -774.66 & \\
\hline Returns to Scale & 1.373 & & 1.456 & & 1.222 & \\
\hline Mean Technical Efficiency & 0.389 & & 0.344 & & 0.511 & \\
\hline
\end{tabular}

Note: Standard errors are in brackets; ** and *** indicate that the coefficients are statistically significant at 5\% and $1 \%$, respectively.

\footnotetext{
${ }^{6}$ The estimated coefficients and standard errors shown for the firm age variable for aggregate manufacturing SMEs, small and medium-sized enterprises, and the Khon Kaen, Udon Thani and Nong Khai provinces, are all insignificant due to the very small number of observations in these categories.
} 
The gamma parameter $(\gamma)$ indicates whether all deviations from the stochastic frontier model are due to random error or technical inefficiency. If gamma $(\gamma)$ is close to zero this indicates that all deviations from the model are caused by random error. However, if gamma $(\gamma)$ is equal to unity, then all deviations are caused by technical inefficiency (Phan 2004; Coelli et al. 2005; Tran et al. 2008). From Table 4 the estimate of the gamma parameter $(\gamma)$ in aggregate manufacturing SMEs is 0.411 , meaning that the variation in the composite error term is due to the inefficiency component. The estimated gamma $(\gamma)$ for small and medium-sized enterprises is equal to 0.204 and 0.001 , respectively, meaning that all deviations from the model are ascribed to random error.

Table 5

Maximum Likelihood Estimates for Parameters of the Stochastic Frontier Model and Technical Inefficiency Effects Model by Selected Three Provinces

\begin{tabular}{|c|c|c|c|c|c|c|}
\hline \multirow{3}{*}{$\begin{array}{ll}\text { Variables } & \\
\text { Number of Observations }\end{array}$} & \multicolumn{2}{|c|}{ Khon Kaen Province } & \multicolumn{2}{|c|}{ Udon Thani Province } & \multicolumn{2}{|c|}{ Nong Khai Province } \\
\hline & \multicolumn{2}{|c|}{1412} & \multicolumn{2}{|r|}{604} & \multicolumn{2}{|r|}{455} \\
\hline & Coefficients & Standard Error & Coefficients & Standard Error & Coefficients & Standard Error \\
\hline \multicolumn{7}{|l|}{ Stochastic Frontier Model } \\
\hline Constant & $5.563 * * *$ & 0.221 & $4.515^{* * *}$ & 0.270 & $5.911 * * *$ & 0.234 \\
\hline Capital & $0.140^{* * *}$ & 0.014 & $0.289 * * *$ & 0.024 & $0.115^{* * *}$ & 0.026 \\
\hline Labour & $1.070^{* * *}$ & 0.053 & $0.867 * * *$ & 0.046 & $1.004 * * *$ & 0.054 \\
\hline \multicolumn{7}{|l|}{ Technical Inefficiency Effects Model } \\
\hline Constant & $3.577^{* * *}$ & 0.409 & $3.361^{* * *}$ & 0.308 & -1.366 & 1.575 \\
\hline Firm Size (dummy) & -0.379 & 0.373 & $-1.510^{* * *}$ & 0.216 & -0.122 & 1.376 \\
\hline Firm Age (year) & 0.006 & 0.007 & $0.011^{* * *}$ & 0.003 & -0.027 & 0.019 \\
\hline Skilled Labour (ratio) & $-1.404^{* * *}$ & 0.195 & 0.027 & 0.334 & $-2.693 * * *$ & 0.713 \\
\hline Municipality (dummy) & $-0.452 * * *$ & 0.122 & $-0.514 * *$ & 0.225 & $-0.961 * * *$ & 0.372 \\
\hline Individual Proprietor (dummy) & $-1.521 * * *$ & 0.182 & $-1.072 * * *$ & 0.222 & $2.878 * * *$ & 0.598 \\
\hline Juristic Partnership (dummy) & $-3.342 * * *$ & 0.782 & $-2.916^{* * *}$ & 0.619 & -5.729 & 4.199 \\
\hline Limited \& Public limited company (dummy) & $-7.086^{* * *}$ & 0.906 & $-5.909 * * *$ & 1.517 & -4.052 & 2.535 \\
\hline Government \& State enterprises (dummy) & -1.088 & 0.957 & $0^{7}$ & 1.000 & $6.781^{* * *}$ & 2.066 \\
\hline Cooperatives (dummy) & 1.259 & 0.997 & $-0.468 * * *$ & 0.998 & 0 & 1.000 \\
\hline \multicolumn{7}{|l|}{ Variance Parameters } \\
\hline Sigma-squared & $1.354^{* * *}$ & 0.077 & $1.229^{* * *}$ & 0.140 & $2.598 * * *$ & 0.370 \\
\hline Gamma & $0.359^{* * *}$ & 0.089 & $0.244^{* * *}$ & 0.030 & $0.818 * * *$ & 0.037 \\
\hline Log-likelihood Function & -2139.06 & & -883.41 & & -666.67 & \\
\hline Returns to Scale & 1.210 & & 1.156 & & 1.119 & \\
\hline Mean Technical Efficiency & 0.363 & & 0.517 & & 0.452 & \\
\hline
\end{tabular}

Note: Standard errors are in brackets; ** and *** indicate that the coefficients are statistically significant at 5\% and $1 \%$, respectively.

\footnotetext{
${ }^{7}$ The estimated coefficients and standard errors shown for the dummy variable for government and state enterprises in the Udon Thani province and co-operatives in the Nong Khai province are insignificant due to the very small number of observations in both categories.
} 
Table 5 shows the results for the selected three provinces. The estimated coefficients of capital $\left(\beta_{1}\right)$ and labour $\left(\beta_{2}\right)$ are positive and they are strongly significant at the $1 \%$ level of significance in the Khon Kaen, Udon Thani and Nong Khai provinces. The input elasticities of capital $\left(\beta_{1}\right)$ and labour $\left(\beta_{2}\right)$, reveal increasing returns to scale in the Khon Kaen, Udon Thani and Nong Khai provinces, because the sum of the estimated input coefficients obtained from the stochastic frontier models are higher than unity (see Table 5). The elasticities of labour $\left(\beta_{2}\right)$ in the stochastic production functions are much higher than capital $\left(\beta_{1}\right)$ for the case of the Khon Kaen, Udon Thani and Nong Khai provinces. From Table 5 the elasticities of labour are 1.070, 0.867 and 1.004, respectively, while the capital elasticities are $0.140,0.289$ and 0.115 , respectively. The share of labour in the production function is higher than capital for the Khon Kaen, Udon Thani and Nong Khai provinces. Hence SMEs in Khon Kaen, Udon Thani and Nong Khai provinces are highly labour intensive. For the gamma parameter $(\gamma)$, the estimate of the variance parameter of gamma $(\gamma)$ in both the Khon Kaen and Udon Thani provinces is 0.359 and 0.244 (see Table 5), respectively, implying that all deviations from the production function are attributable to noise. The estimated gamma parameter $(\gamma)$ of the Nong Khai province is 0.818 (see Table 5), indicating that all deviations from the model are attributable to technical inefficiency.

\section{Results from the Technical Inefficiency Effects Model}

The estimated results, in terms of the signs of the coefficients and their significance, for Equations (1) and (3), are presented in Table 6. All negative coefficient signs of the technical inefficiency effects model represent the relationship relative to technical inefficiency. However, all negative signs must be converted to positive for their relationship to technical efficiency.

\section{Firm Size}

Firm size is one of the significant firm-specific factors influencing a firm's performance. A number of empirical studies have found that the size of a firm has a significant and positive relationship with its technical efficiency (Lundvall \& Battese 2000; Admassie \& Matambalya 2002; Yang 2006; Tran et al. 2008; Amornkitvikai \& Harvie 2011). The estimated coefficients for firm size have negative signs for aggregate manufacturing SMEs, and the Khon Kaen, Udon Thani and Nong Khai provinces. However, only the coefficient for the Udon Thani province is statistically significant at the $1 \%$ level of significance. This indicates that small-sized enterprises are more efficient than medium-sized enterprises for the case of the Udon Thani province. The coefficients of aggregate manufacturing SMEs, the Khon Kaen and Nong Khai provinces are not statistically significant. A recent study of the technical efficiency performance of Vietnamese manufacturing SMEs found that firm size has a negative association with technical inefficiency (Le 2010). The flexibility of smallsized firms can enable them to quickly diversify to become more efficient. 


\section{Firm Age}

Firm age is another firm-specific factor contributing to a firm's technical efficiency. Many empirical studies have found that firm age has a statistically positive impact upon a firm's technical efficiency (Admassie \& Matambalya 2002; Batra \& Tan 2003; Tran et al. 2008; Amornkitvikai \& Harvie 2011). The estimates of the coefficients for firm age have negative signs for small and medium-sized enterprises and the Nong Khai province, but positive signs for aggregate manufacturing SMEs, and the Udon Thani and Khon Kaen provinces. However, only the coefficient of the Udon Thani province is statistically significant at the $1 \%$ level of significance. This indicates that firm age is negatively related to a firm's technical efficiency in this province.

\section{Skilled Labour}

The estimated coefficients for skilled labour, represented by the ratio of skilled labour to total workers, are negative and highly significant at the $1 \%$ level of significance in four categories, including aggregate manufacturing SMEs, small enterprises, and the Khon Kaen and Nong Khai provinces. This implies that skilled labour has a positive association with a firm's technical efficiency. Skilled labour is one of the most important factors affecting SME development in Thailand (Regnier 2000; Huang 2003). Several empirical studies have found that skilled labour is positively related to firm technical efficiency (Admassie \& Matambalya 2002; Zahid \& Mokhtar 2007; Amornkitvikai \& Harvie 2011). However, estimates of the coefficients for skilled labour has a positive sign for medium-sized enterprises and the Udon Thani province, but only the coefficient of medium enterprises is statistically significant. This result indicates that skilled labour has a negative impact on the technical efficiency of medium sized enterprises.

\section{Municipality}

Results concerning the dummy variable for municipality exhibit a negative sign in five categories, including aggregate manufacturing SMEs, small enterprises, and the Khon Kaen, Udon Thani and Nong Khai provinces. The coefficients for aggregate manufacturing SMEs, small enterprises, and the Khon Kaen and Nong Khai provinces are highly significant at the $1 \%$ level, while the coefficient of the Udon Thani province is statistically significant at the $5 \%$ level of significance. These results suggest that municipal area has a positive relationship with a firm's technical efficiency. The metropolitan efficiency effect is suggestive of agglomeration economies in the private sector, as a consequence of the availability of more highly educated workers and managers, and better infrastructure and market opportunities in metropolitan areas relative to non-metropolitan areas (Tran et al. 2008). Many studies reveal that a municipal area has a positive impact on technical efficiency (Krasachat 2000; Li \& Hu 2002; Yang 2006; Le \& Harvie 2010). Only the estimated coefficient for medium-sized enterprises shows a positive sign, but it is not statistically significant (see Table 6). 
Table 6

Results from the Technical Inefficiency Effects Model for Manufacturing SMEs in the North-eastern Region

\begin{tabular}{lcccccc}
\hline Technical Inefficiency Effects & $\begin{array}{c}\text { Aggregate } \\
\text { Manufacturing SMEs }\end{array}$ & $\begin{array}{c}\text { Small } \\
\text { Enterprises }\end{array}$ & $\begin{array}{c}\text { Medium } \\
\text { Enterprises }\end{array}$ & $\begin{array}{c}\text { Khon Kaen } \\
\text { Province }\end{array}$ & $\begin{array}{c}\text { Udon Thani } \\
\text { Province }\end{array}$ & $\begin{array}{c}\text { Nong Khai } \\
\text { Province }\end{array}$ \\
\hline Constant & $+* * *$ & $+* * *$ & $+* * *$ & $+* * *$ & $+* * *$ & $+* * *$ \\
Firm Size & - & $\mathrm{N} / \mathrm{A}$ & $\mathrm{N} / \mathrm{A}$ & - & $-* * *$ & - \\
Firm Age & + & - & - & + & $+* * *$ & - \\
Skilled Labour & $-* * *$ & $-* * *$ & $+* *$ & $-* * *$ & + & $-* * *$ \\
Municipality & $-* * *$ & $-* * *$ & + & $-* * *$ & $-* *$ & $-* * *$ \\
Individual Proprietor & $-* * *$ & $-* * *$ & $-* *$ & $-* * *$ & $-* * *$ & $+* * *$ \\
Juristic Partnership & $-* * *$ & $-* * *$ & $-* * *$ & $-* * *$ & $--* *$ & - \\
Limited \& Public Limited Companies & $-* * *$ & $-* * *$ & $-* * *$ & $-* * *$ & $--* *$ & - \\
Government \& State-owned Enterprises & $+* * *$ & - & $+* * *$ & - & + & $+* * *$ \\
Co-operatives & $-* *$ & $-* *$ & - & + & $-* * *$ & + \\
\hline
\end{tabular}

Note: ${ }^{* *}$ and ${ }^{* * *}$ indicate that the coefficients are statistically significant at $5 \%$ and $1 \%$, respectively.

\section{Individual Proprietor}

Estimates of the coefficients for individual proprietor have negative signs for five categories, aggregate manufacturing SMEs, small and medium sized enterprises, and the Khon Kaen and Udon Thani provinces. The negative coefficients in all five categories confirm a positive relationship between the individual proprietor and a firm's technical efficiency. The coefficients of aggregate manufacturing SMEs, small enterprises, and the Khon Kaen and Udon Thani provinces are strongly significant at the $1 \%$ level of significance, while the coefficient for medium-sized enterprises is statistically significant at the $5 \%$ level of significance. From these results it can be suggested that individual proprietor ownership is positively related to a firm's technical efficiency. The benefits of an individual or sole proprietor are (Cooper \& Dunkelberg 2006; Ha 2006): (1) complete control over decision-making in a business; (2) the sale or transfer of the business can operate at the discretion of an individual or sole proprietor; (3) minimal legal costs are required to enter the market; and (4) there are fewer legal and reporting requirements. However, the estimated coefficient for the Nong Khai province shows a positive sign, and it is statistically significant at the $1 \%$ level of significance. The positive sign for the Nong Khai province indicates that individual proprietor ownership has a negative association with a firm's technical efficiency in this province.

\section{Juristic Partnership}

The estimated coefficients for juristic partnership exhibit negative signs for all categories, and they are strongly significant at the $1 \%$ level of significance, except for the Nong Khai province. The negative coefficients imply that the juristic partnership form of ownership has a significant and positive effect on the technical efficiency of firms. As compared to an individual or sole proprietorship, a juristic partnership has the advantage of allowing the owner to draw on the resources and expertise of co-partners. Within a juristic partnership, partners share responsibilities and jointly solve barriers to doing business (Fay 1998; Cooper \& Dunkelberg 2006; Fernández \& Nieto 2006). 


\section{Limited and Public Limited Companies}

The estimated coefficients for limited and public limited companies show negative signs in all categories, and they are highly significant at the $1 \%$ level, except for the Nong Khai province. The negative coefficients imply that limited and public limited companies are positively related to a firm's technical efficiency. The advantages of being a limited and public limited company are (Cooper \& Dunkelberg 2006; Fernández \& Nieto 2006; Ha 2006): (1) a legal existence which separates management from shareholders; (2) a company can continue despite the resignation or bankruptcy of management and its members; and (3) new shareholders and investors can be easily incorporated and employees can acquire shares.

\section{Government and State-owned Enterprises}

The estimated coefficients for government and state-owned enterprises have positive signs in four categories, including aggregate manufacturing SMEs, medium enterprises, and the Udon Thani and Nong Khai provinces, and negative signs in the remaining two categories, small enterprises and the Khon Kaen province. The coefficients for aggregate manufacturing SMEs, medium enterprises and the Nong Khai province are highly significant at the $1 \%$ level of significance, while the coefficient for the Udon Thani province is insignificant. Hence, government and state ownership of enterprises is negatively associated with firm technical efficiency. Weak corporate governance and business practices, corruption, and a lack of competition are all prevalent explanations of the poor efficiency performance of these enterprises (Brimble et al. 2002; Sahakijpicharn 2007; OSMEP 2007b). However, the negative coefficients of small enterprises and the Khon Kaen province are not statistically significant.

\section{Co-operatives}

Results for the estimated coefficients of this type of ownership indicate negative signs for four categories, comprising aggregate manufacturing SMEs, small and medium sized enterprises, and the Udon Thani province, while the coefficients for the Khon Kaen and Nong Khai provinces have positive signs. The coefficients for aggregate manufacturing SMEs and small enterprises are statistically significant at the $5 \%$ level, and the Udon Thani province is strongly significant at the $1 \%$ level, while that for medium-sized enterprises are insignificant. The coefficients of the remaining categories are not significant. It can be concluded that co-operatives have a statistically positive association with a firm's technical efficiency. The advantages of a cooperative firm are: (1) all shareholders must be active in the co-operative; (2) shareholders have an equal vote at general meetings regardless of their level of shareholding or involvement in the co-operative; and (3) a cooperative is owned and controlled by its members (Cooper \& Dunkelberg 2006; Thuvachote 2007). 
Table 7 presents the technical efficiency levels of manufacturing SMEs in the North-eastern region. Average technical efficiency ranges from $52 \%$ in the Udon Thani province to $34 \%$ in small enterprises. Medium sized enterprises have the second highest percentage of mean technical efficiency at $51 \%$. The Nong Khai province ranked third at $45 \%$ mean technical efficiency. The Khon Kaen province ranked fourth for technical efficiency at $37 \%$. Small enterprises ranked fifth at $34 \%$ mean technical efficiency. The average technical efficiency of aggregate manufacturing SMEs is $40 \%$. Finally, the average technical efficiency of all categories of manufacturing SMEs in the North-eastern region is $43 \%$, suggesting a high degree of technical inefficiency in the operation of these enterprises. This presents major challenges to both SME owners and government policy makers operating in these provinces.

Table 7

Average Technical Efficiency of Manufacturing SMEs in the North-eastern Region

\begin{tabular}{lc}
\hline Categories & Average Technical Efficiency \\
\hline Aggregate manufacturing SMEs & 0.40 \\
Small Enterprises & 0.34 \\
Medium Enterprises & 0.51 \\
Khon Kaen Province & 0.37 \\
Udon Thani Province & 0.52 \\
Nong Khai Province & 0.45 \\
Overall Average Technical Efficiency & $\mathbf{0 . 4 3}$
\end{tabular}

\section{Conclusions and Policy Implications}

This study has applied both the stochastic frontier production function and technical inefficiency effects model to analyse the technical efficiency of manufacturing SMEs in three provinces in the North-eastern region of Thailand. Cross-sectional data from a 2007 industrial census was used. Data for manufacturing SMEs in the North-eastern region was categorised into: aggregate manufacturing SMEs, small enterprises, medium-sized enterprises, and by three provinces in the North-eastern region. These categories of manufacturing SMEs in the North-eastern region were estimated individually to predict their technical efficiency level and investigate whether technical efficiency is positively or negatively related to firm-specific factors, such as firm size, firm age, skilled labour, location (municipal and non-municipal areas) and ownership characteristics.

The empirical results indicated that the average technical efficiency of all categories of manufacturing SMEs in the North-eastern region is only $43 \%$. The Udon Thani province had the highest percentage of average technical efficiency at 52\%. The lowest percentage of average technical efficiency was small enterprises at 34\%. Manufacturing SMEs in the North-eastern region, therefore, have high levels of technical inefficiency in their production processes. Furthermore, manufacturing SMEs in the North-eastern region appear to be focused upon low skilled, highly labour intensive and low value adding activities. 
Empirical results from the technical inefficiency effects model also indicate that small sized enterprises are more technically efficient than medium sized enterprises in only one category, which is the Udon Thani province. Firm age has a significant and negative association with a firm's technical efficiency only in the Udon Thani province. Skilled labour is found to be an important factor affecting the technical efficiency of manufacturing SMEs in the North-eastern region. Location in a municipal area is also likely to be a significant factor for technical efficiency, indicating the importance of agglomeration economies. Ownership characteristics - individual proprietor, juristic partnership, public and limited company - were also important firm-specific factors contributing to a firm's technical efficiency for the majority of categories. There was also evidence to indicate that the co-operative form of ownership was also important for technical efficiency. In general, government and state-owned manufacturing enterprises appeared to be technically inefficient, although this depended on the province and the size of firm.

From a policy perspective, based upon the results from this study, it is recommended that the Thai government encourage the development of manufacturing SMEs in the North-eastern provinces through: (1) upgrading skills using targeted training programs for employees and entrepreneurs; (2) encouraging greater use of capital and technology in the production processes of SMEs; (3) enhance the efficiency of state-owned manufacturing enterprises, which could consist of privatisation; (4) encourage all forms of firm ownership, although limited and public limited forms of ownership have the greatest potential to improve SME technical efficiency, followed by juristic partnerships and then individual ownership in that order; ${ }^{8}(5)$ encourage co-operatively owned small firms in the Udon Thani province; and (6) improve infrastructure and building upon agglomeration economies that are apparent in municipal areas. These measures can be usefully supplemented by encouraging and facilitating innovative activity, through firm collaboration and networking, facilitating greater access to and uptake of technology, improving information and communications technology infrastructure and enhancing access to finance.

\footnotetext{
${ }^{8}$ See Tables 5 and 6.
} 


\section{References}

Admassie, A \& Matambalya, FAST 2002, 'Technical Efficiency of Small-and Medium-Scale Enterprises: Evidence from a Survey of Enterprises in Tanzania', Eastern Africa Social Science Research Review, vol. 18, no. 2, pp. 1-29. http://dx.doi.org/10.1353/eas.2002.0007

Amornkitvikai, Y \& Harvie, C 2011, 'Finance, Ownership, Executive Remuneration, and Technical Efficiency: A Stochastic Frontier Analysis (SFA) of Thai Listed Manufacturing Enterprises', Australasian Accounting Business and Finance Journal, vol. 5, no. 1, pp. 35-55.

Arunsawadiwong, S 2007, 'Productivity Trends in the Thai Manufacturing Sector: The Pre- and PostCrisis Evidence Relating to the 1997 Economic Crisis', PhD Thesis, School of Economics and Finance, University of St. Andrews, Scotland.

Batra, G \& Tan, H 2003, SME Technical Efficiency and Its Correlates: Cross-National Evidence and Policy Implication, World Bank Institute, Working Paper, Washington DC.

Battese, GE \& Coelli, TJ 1995, 'A Model for Technical Inefficiency Effects in a Stochastic Frontier Production Function for Panel Data', Empirical Economics, vol. 20, pp. 325-332. http://dx.doi.org/10.1007/BF01205442

Battese, GE \& Corra, GS 1977, 'Estimation of a Production Frontier Model: With Application to the Pastoral Zone of Eastern Australia', Australian Journal of Agricultural Economics, vol. 21, pp. 169-179. http://dx.doi.org/10.1111/j.1467-8489.1977.tb00204.x

Brimble, P, Oldfield, D \& Monsakul, M 2002, Policies for SME Recovery in Thailand, The Role of SMEs in National Economies in East Asia, Charles Harvie and Boon-Chye Lee (eds), Edward Elgar, Cheltenham.

Charoenrat, T, Harvie, C \& Amornkitvikai, Y 2010, Technical Efficiency of Thai Manufacturing SMEs: Evidence from a Firm-level Industrial Census, The 7th SMEs in a Global Economy Conference: Challenges and Prospects, Kuching, Sarawak, Malaysia, 15-17 October.

Coelli, TJ 1995, 'Recent Developments in Frontier Modelling and Efficiency Measurement', Australian Journal of Agricultural Economics, vol. 39, no. 3, pp. 219-245.

http://dx.doi.org/10.1111/j.1467-8489.1995.tb00552.x

Coelli, TJ 1996a, A Guide to FRONTIER Version 4.1: A Computer Program for Stochastic Frontier Production and Cost Function Estimation, Working paper 96/07, Centre for Efficiency and Productivity Analysis, Armidale, University of New England.

Coelli, TJ 1996b, A Guide to DEAP Version 2.1: A Data Envelopment Analysis (Computer) Program, Working paper 96/08, Centre for Efficiency and Productivity Analysis, Armidale, University of New England.

Coelli, TJ, Rao, DSP, O'Donnell, CJ \& Battese, GE 2005, An Introduction to Efficiency and Productivity Analysis, 2nd edn, Springer, New York.

Cooper, AC \& Dunkelberg, WC 2006, 'Entrepreneurship and Paths to Business Ownership', Strategic Management Journal, vol. 7, no. 1, pp. 53-68. http://dx.doi.org/10.1002/smj.4250070106 
Fay, JR 1998, 'What Form of Ownership is Best?', CPA Journal, vol. 68, no. 8, pp. 1-3.

Fernández, Z \& Nieto, MJ 2006, 'Impact of Ownership on the International Involvement of SMEs', Journal of International Business Studies vol. 37, pp. 340-351.

http://dx.doi.org/10.1057/palgrave.jibs.8400196

Greene, W 2003, 'Simulated Likelihood Estimation of the Normal-Gamma Stochastic Frontier Function', Journal of Productivity Analysis, vol. 19, pp. 179-190. http://dx.doi.org/10.1023/A:1022853416499

Gregory, G, Havie, C \& Lee, HH 2002, 'Korean SMEs in the 21st Century: Strategies, Constraints and Performance in a Global Economy', Economic papers, vol. 21, no. 3, pp. 64-79.

Ha, TT 2006, 'Entrepreneurial Orientation, Business Strategies and Firm Performance: A Comparative Study of Small and Medium-Scale Enterprises in Vietnam and Thailand', PhD Thesis, Asian Institute of Technology, Bangkok.

Harvie, C 2008, SME Development Strategy in Vietnam, Small and Medium Sized Enterprises in East Asia: Sectoral and Regional Dimensions, Charles Harvie and Boon-Chye Lee (eds), Edward Elgar, Cheltenham.

Huang, I-W 2003, 'Importance of SMEs Development in Thailand', Forum of International Development Studies, vol. 23, pp. 159-176.

Kim, S 2003, 'Identifying and Estimating Sources of Technical Inefficiency in Korean Manufacturing Industries', Contemporary Economic Policy, vol. 21, no. 1, pp. 132-144. http://dx.doi.org/10.1093/cep/21.1.132

Kodde, DA \& Palm, FC 1986, 'Wald Criteria for Jointly Testing Equality and Inequality Restrictions ', Econometrica, vol. 54, no. 5, pp. 1243-1248 http://dx.doi.org/10.2307/1912331

Kontodimopoulos, N, Papathanasiou, ND, Flokou, A, Tountas, Y \& Niakas, D 2010, 'The Impact of Non-Discretionary Factors on DEA and SFA Technical Efficiency Differences', Journal of Medical Systems, vol. DOI 10.1007/s10916-010-9521-0, pp. 1-9.

Krasachat, W 2000, Measurement of Technical Efficiency in Thai Agricultural Production, The International Conference on the Chao Praya Delta: Historical Development, Dynamics and Challenges of Thailand's Rice Bowl, Bangkok, Thailand, 2-15 December.

Le, CLV 2010, 'Technical Efficiency Performance of Vietnamese Manufacturing Small and Medium Enterprises', PhD Thesis, School of Economics, Faculty of Commerce, University of Wollongong.

Le, V \& Harvie, C 2010, 'Firm Performance in Vietnam: Evidence from Manufacturing Small and Medium Enterprises', University of Wollongong Economics, Working Paper Series 04-10, pp. $1-33$.

Li, Y \& Hu, JL 2002, 'Technical Efficiency and Location Choice of Small and Medium-Sized Enterprises', Small Business Economics, vol. 19, pp. 1-12.

http://dx.doi.org/10.1023/A:1015770220239 
Lundvall, K \& Battese, GE 2000, 'Firm Size, Age and Efficiency: Evidence from Kenyan Manufacturing Firms', The Journal of Development Studies, vol. 36, no. 3, pp. 146-163. http://dx.doi.org/10.1080/00220380008422632

Mephokee, C 2003, The Thai SMEs Development Policies: Country Report, Thammasat University, Bangkok.

NSO 2011, The 2007 Industrial Census, National Statistical Office of Thailand, accessed 13/05/2010, http://web.nso.go.th/eng/en/stat/indus/indus00.htm.

OECD 2011, OECD Studies on SMEs and Entrepreneurship Thailand: Key Issues and Policies, Organisation for Economic Co-operation and Development, Paris.

OSMEP 2001, Executive Summary of White Paper on SMEs in 2001, Office of Small and Medium Enterprises Promotion, Bangkok.

OSMEP 2002, The White Paper on Small and Medium Enterprises of Thailand in 2002 and Trends 2003, Office of Small and Medium Enterprises Promotion, Bangkok.

OSMEP 2003, The White Paper on Small and Medium Enterprises of Thailand in 2003 and Trends 2004, Office of Small and Medium Enterprises Promotion, Bangkok.

OSMEP 2004, The White Paper on Small and Medium Enterprises of Thailand in 2004 and Trends 2005, Office of Small and Medium Enterprises Promotion, Bangkok.

OSMEP 2005, The White Paper on Small and Medium Enterprises of Thailand in 2005 and Trends 2006, Office of Small and Medium Enterprises Promotion, Bangkok.

OSMEP 2006, The White Paper on Small and Medium Enterprises of Thailand in 2006 and Trends 2007, Office of Small and Medium Enterprises Promotion, Bangkok.

OSMEP 2007a, The White Paper on Small and Medium Enterprises of Thailand in 2007 and Trends 2008, Office of Small and Medium Enterprises Promotion, Bangkok.

OSMEP 2007b, The 2nd SME Promotion Plan (2007-2011), Office of Small and Medium Enterprises Promotion, Bangkok.

OSMEP 2008, The White Paper on Small and Medium Enterprises of Thailand in 2008 and Trends 2009, Office of Small and Medium Enterprises Promotion, Bangkok.

Phan, P 2004, 'Trade Liberalisation and Manufacturing Performance in Thailand 1990-2000', PhD Thesis, School of Economics, Faculty of Commerce, University of Wollongong.

Regnier, P 2000, Small and Medium Enterprises in Distress: Thailand, The East Asian Crisis and Beyond, Ashgate Publishing, Burlington.

Sahakijpicharn, K 2007, 'Guanxi Network and Business Performance of Sino-Thai SMEs', PhD Thesis, School of Economics, Faculty of Commerce, University of Wollongong.

Tapaneeyangkul, P 2001, Government Policies in Assisting SMEs for Sustainable Development, The Office of Small and Medium Enterprise Promotion, Bangkok. 
Thuvachote, S 2007, Agricultural Cooperatives in Thailand: Innovations and Opportunities in the 21st Century, Department of Cooperatives, Faculty of Economics, Kasetsart University, Bangkok.

Tran, TB, Grafton, RQ \& Kompas, T 2008, 'Firm Efficiency in a Transitional Economy: Evidence from Vietnam', Asian Economic Journal, vol. 22, no. 1, pp. 47-66.

http://dx.doi.org/10.1111/j.1467-8381.2008.00268.x

UNSD 2011, International Standard Industrial Classification of All Economic Activities, ISIC: Revision 3, United Nations Statistics Division, accessed 11/05/2011, http://unstats.un.org/unsd/cr/registry/regcst.asp?cl=2.

Vu, QN 2003, 'Technical Efficiency of Industrial State-Owned Enterprises in Vietnam', Asian Economic Journal, vol. 17, no. 1, pp. 87-101. http://dx.doi.org/10.1111/1351-3958.00163

Wiboonchutikula, P 2002, 'Small and Medium Enterprises in Thailand: Recent Trends ', Small Business Economics, vol. 18, pp. 213-226. http://dx.doi.org/10.1023/A:1015143709196

Yang, JC 2006, 'The Efficiency of SMEs in the Global Market: Measuring the Korean Performance', Journal of Policy Modeling, vol. 28, pp. 861-876. http://dx.doi.org/10.1016/j.jpolmod.2006.07.004

Zahid, Z \& Mokhtar, M 2007, Estimating Technical Efficiency of Malaysian Manufacturing Small and Medium Enterprises: A Stochastic Frontier Modelling, The 4th SMEs in a Global Economy Conference, University of Wollongong, 9-10 July. 
AABFJ | Volume 7, no. 1, 2013 